\title{
Effect of Freshwater Crab Shell Fog as Organic Fertilizer to Increase Plants of Cucurbitaceae Growth Dramatically
}

\author{
Surya Anjani Kumar Sarva ${ }^{1^{*}}$ and Archana Giri ${ }^{2}$ \\ ${ }^{1}$ Research scholar, Plant Biotechnology, JNTU Hyderabad, India \\ ${ }^{2}$ Department of Biotechnology, IST, JNTU Hyderabad, India
}

"Corresponding author: Surya Anjani Kumar Sarva, Research Scholar, Plant Biotechnology, JNTU Hyderabad, India, Tel: +919000146000; E-mail: s.anjanikumar@gmail.com

Rec date: May 31, 2014, Acc date: Oct 13, 2014, Pub date: Oct 15, 2014

Copyright: (c) 2014 Sarva SAK, et al. This is an open-access article distributed under the terms of the Creative Commons Attribution License, which permits unrestricted use, distribution, and reproduction in any medium, provided the original author and source are credited.

\begin{abstract}
Chitin from Fresh water Crabs is observed to have appreciable effect on cucurbitaceae specifically. When the plant is smoked with dried powder of chitin, plant showed good response in its Growth, Maturation, Disease Resistance, Color, and Size of the Fruit and Leaf. The topic was extracted from an ancient book Vyrukshaveda written by an eminent sage Surapala in 1000 B.C. According to Surapala when plants are smoked with Crab shell powder plants show good sprouting and healthy growth.

From the literature it is evident that Chitin is active against viruses, bacteria and other pests. Fragments from chitin are known to have eliciting activities leading to a variety of defense responses in host plant. Based on these and other properties that help to strengthen host plant defense, interest has been grown in using the technique in agricultural systems to reduce the negative impact of diseases on yield and quality of crops. Taking these as focus points for research the present work emphasizes on crab shell smoke's mode of action on plants, yield studies and Disease Resistance specifically in cucurbitaceae. The use of this simple technique by farmers will help them in improving their yield and in turn their profits.
\end{abstract}

Keywords: Vyrukshaveda; Surapala; Phytoalexins; Pathogen related proteins; Chitin

\section{Introduction}

Fertilizers are important chemicals compounds used for cultivation. Fertilizers play important role in growth, maturation and yield of plants. Fertilizers used in large quantities by farmers are highly inorganic. They use these fertilizers to increase the yield. An inorganic fertilizer provides satisfactory output, but on the other hand they affect to the nativity of the soil texture, growth of plant and its yield. Huge amounts of toxic residues accumulated in soil will affect plants, fruits and vegetables. Consuming these may lead to many health disorders leading to some life threatening diseases. A safe way to solve these problems is to opt for organic fertilizers [1].

Organic cultivation has become a major practice these days. Farmers are getting attracted towards organic cultivation as they could able to see the difference between organic and inorganic farming. Organic fertilizers provide nourishment to both plant and soil. They help in conditioning soil texture and in turn help the plant grow organically [2,3]. Just like inorganic fertilizers, organic fertilizers also have promising results on various crops. Organic farming includes usage of microbes like Nitrogen fixing bacteria, Phosphate Solubilizing bacteria, plant growth promoters etc. Usage of Plant extracts, Animal by-products etc. are discusses way back in ancient cultivation methods. Famous sages of 1000 B.C like Varahamihara, Surapala etc. gave formulations for some miraculous concepts in plant biology. Some most accepted and widely practiced concepts are taken from Surapala's VYRUKSHAYURVEDA which explains about techniques for plant Nourishment, plant healing, plant self-defense etc. by using plant extracts and Animal byproducts [4-6].

\section{Present topic was selected from Vyrukshayurveda's verses}

- "If, the branches burnt off, they should be cut and the spots should be sprinkledwith water, milk. Smoking done with shells of crab leads to fresh sprouts." (V.204)

- "If the drying is due to the lack of water, the trees should be watered with milk-water and properly fomented by the smoke of crab shells."(V.209)

- Ash guard and cucumber dies if profusely smoked with bones of crabs. (V.275)

Taking into consideration of the above three verses; present work concentrates on practical studies to observe growth, sprouting, regeneration etc. Specifically present work tried to bring out the point that smoking cucurbitaceae with freshwater crab shell will enhance the growth rather than hampering the growth as said in the verse (V.275). Crab shell when powdered and fogged on plants showed very good result on plant growth, maturation, yield etc. There are some other practices where Chitin from crab shell is utilized as potent plant growth promoters, but studies have found that the fog of Freshwater crabs showed promising results. The most exciting feature of the freshwater crab shell fog is that it shows its action on Cucurbitaceae specifically [7-9].

\section{Materials and Methods}

Ash Gourd was selected for work as it is the season and plant is easy to study for phenotypic changes. F1 Hybrid seeds of ash gourd of Kailash seeds Pvt. Ltd. were taken for the work. Soil used to grow these 
Citation: Sarva SAK, Giri A (2014) Effect of Freshwater Crab Shell Fog as Organic Fertilizer to Increase Plants of Cucurbitaceae Growth Dramatically. Agrotechnol 4: 129. doi:10.4172/2168-9881.1000129

Page 2 of 4

seeds was checked for NPK values and found to be normal; this is done to rule out the point that soil nutrients are responsible for the nourishment and growth of the plant. Soil testing values are shown in the Table 1.

\begin{tabular}{|l|l|l|}
\hline S. No & Parameters & Results \\
\hline 1 & $\mathrm{p}^{\mathrm{H}}$ & 7.38 \\
\hline 2 & Nitrogen & 0.58 \\
\hline 3 & Phosphorous & 0.23 \\
\hline 4 & Potassium & 0.18 \\
\hline
\end{tabular}

Table 1: Soil analysis report with NPK values of test soil.

Seed were sown into the tested soil and incubated under normal conditions. Pots were differentiated as TEST, CONTROL and SEED
TREATED. Seed treatment was done by shaking the seeds and the powder vigorously for $30 \mathrm{mins}$ at $10 \mathrm{mins}$ interval. Seeds thus treated are sown along with test and control in a separate pot [10].

\section{Chitin powder preparation}

Paratelphusa hydrodromus paddy field crab a natural species of costal Andhra Krishna district, was collected. The shells were removed dried at $60 \mathrm{oC}$ for 6 hours, dried shells are powered by pestle and Mortar into fine powder thus obtained powder was procured and kept for further use.

After allowing plants to grow for a period of 20-days, plants having better morphology were separated from germination pots and sown into bigger pots for further growth. The growth of the seeds had sown showed normal growth till the plants are smoked with crab shell powder (Figure 1)
A

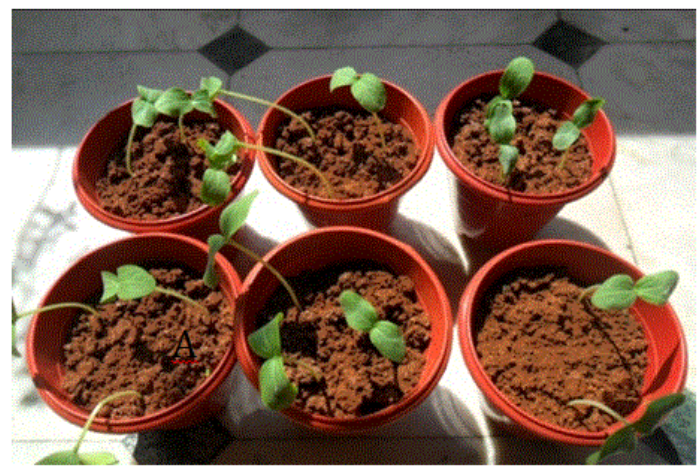

B

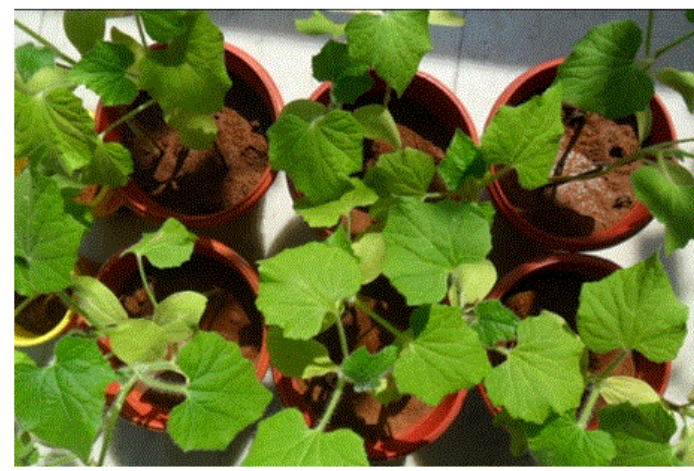

Figure 1: Shows growth of the seeds showed A) shows growth after 6-days B) Shows growth after 20-days.

\begin{tabular}{|c|c|c|c|}
\hline Morphology & Chitin Treated & Crab shell smoked & Control \\
\hline \multirow{3}{*}{$\begin{array}{l}\text { Height of the plant } \\
\text { Before fogging } \\
\text { After fogging }\end{array}$} & \multirow{2}{*}{$\begin{array}{l}95 \mathrm{cms} \\
-\end{array}$} & \multirow[t]{2}{*}{$1 \mathrm{mts} 15 \mathrm{cms}$} & $2 \mathrm{mts} 20 \mathrm{cms}$ \\
\hline & & & - \\
\hline & - & $3 \mathrm{mts} 80 \mathrm{cms}$ & - \\
\hline \multirow{3}{*}{$\begin{array}{l}\text { Size of leaf } \\
\text { Before fogging } \\
\text { After fogging }\end{array}$} & $13.7 \mathrm{cms}(\mathrm{w}) 11.5(\mathrm{~L})$ & - & $18 \mathrm{cms}(\mathrm{w}) 16 \mathrm{~cm}(\mathrm{~L})$ \\
\hline & - & $14 \mathrm{cms}(\mathrm{w}) 11.6(\mathrm{~L})$ & - \\
\hline & - & $20.2 \mathrm{cms}(\mathrm{w}) 16.2 \mathrm{cms}(\mathrm{L})$ & - \\
\hline \multirow{3}{*}{$\begin{array}{l}\text { Number of Flowers } \\
\text { Before fogging } \\
\text { After fogging }\end{array}$} & 9 & - & 9 \\
\hline & - & 6 & - \\
\hline & - & 17 & - \\
\hline
\end{tabular}

Table 2: Average calculations of Morphological characters of plants; Measurements are taken after 30 days from fogging plants.

\section{Fogging of crab-shell powder on plants}

After 30 days plants were smoked with chitin powder. Charcoal mould is used as fire source. Crab shell powder was burnt to ashes to produce smoke thus produced smoke is fogged on to plant during evening time. The plants were left for further growth. 
Citation: Sarva SAK, Giri A (2014) Effect of Freshwater Crab Shell Fog as Organic Fertilizer to Increase Plants of Cucurbitaceae Growth Dramatically. Agrotechnol 4: 129. doi:10.4172/2168-9881.1000129

Page 3 of 4

\section{Result and Discussion}

After 30 days the smoked plants along with control are observed for response of crab shell fogging. Certain parameters like Height, size of leaf and number of flowers are considered for result study in the plant. Results are tabulated in Table 2 (Figures 2-4).

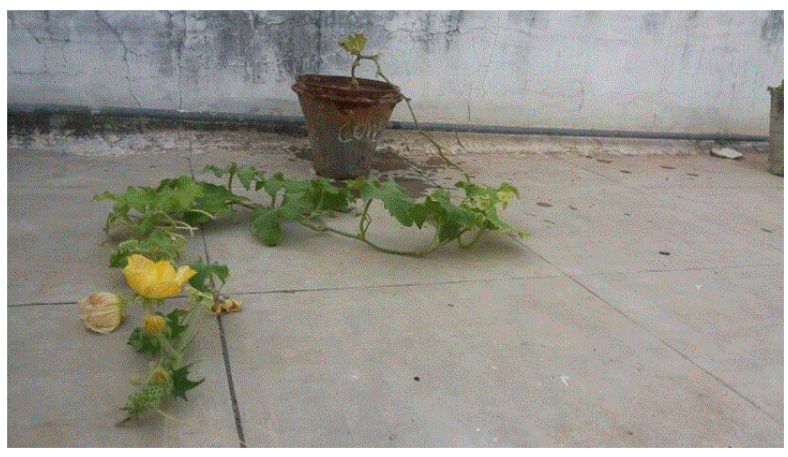

Figure 2: Plant sprouted from Control seed.

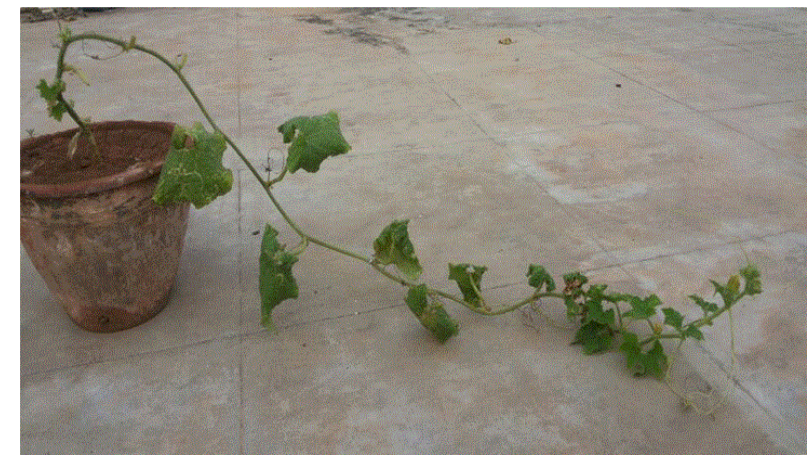

Figure 3: Plant sprouted from seed treated with chitin.

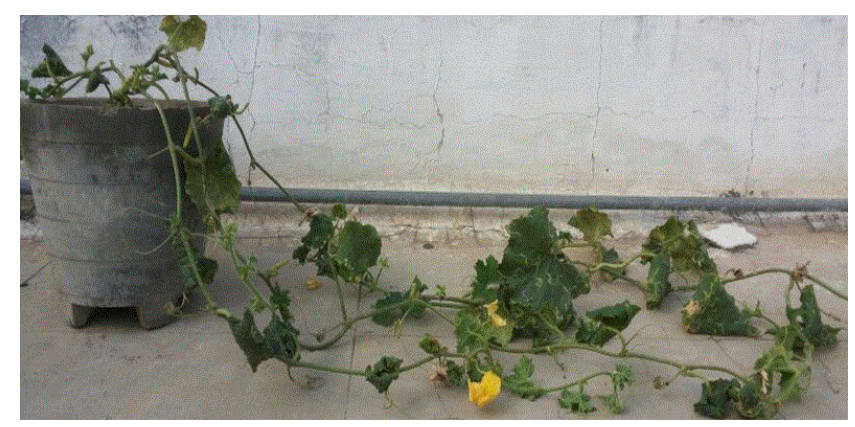

Figure 4: Plant sprouted from Test seed prior smoking.
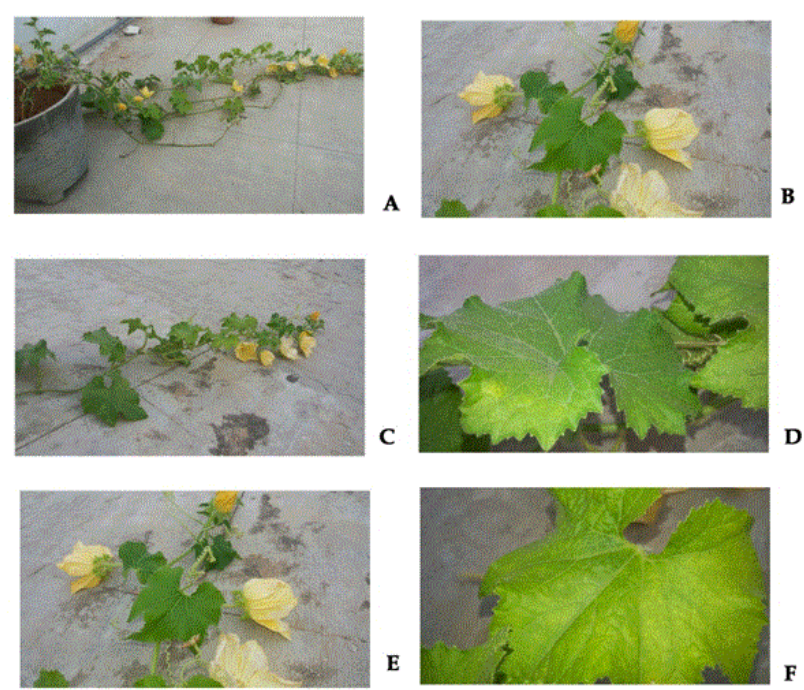

Figure 5: A) Shows growth of the plant after smoking with crab shell; B, C, E) Shows increase in flower count; D, F) Shows increase in size of leaf lamina and increase in the chlorophyll content.

From the observation obtained from Table 2 it is understood that smoke has constructive effect on the plant growth rather than the soil in which seeds were shown. When the seeds were treated before sowing they showed early growth. From Table 2 it is understood the smoking enhanced the growth of the plant, its length, number of flowers. Thus as stated in the verse 209 in Vyrukshayurveda crab shell smoke helps in increasing growth and new sprouting it is clearly observed. One of the other finds which we came across was smoke not only enhanced sprouting it also increased the number of flowers and increased the length of lamina (Figure 5). These findings were not observed when the same procedure is followed for other plants except the plants of cucurbitaceae, this gave strength to the work in proving that the smoke will enhance the growth rather than hampering it.As the smoke shows effect on Cucurbitaceae, further studies are concentrated on identifying the responsible volatile compound its structure and mechanism of action on cucurbitaceae.

\section{References}

1. Hong KN, Mun YL (1995) Isolation of chitin from crab shell waste. J Korean Soc Food Nutr 24: 105-113.

2. Cho YI, HK No (1999) Effective deproteinization under autoclaving conditions for preparation of chitin. J Chitin Chitosan 4: 152-155.

3. Majeti NV, Kumar R (2000) A review of chitin and chitosan applications. React Fun Polymers 46: 1-27.

4. Nalini S (1996) Surapala's Vrikshayurveda (The Science of Plant Life by Surapala). Agri-History Bulletin 1: 94.

5. Light ME, Burger BV, van Staden J (2005) Formation of a seed germination promoter from carbohydrates and amino acids. J Agric Food Chem 53: 5936-5942.

6. Nene YL (2005) Rice research in South Asia through ages. Asian AgriHistory 9: 85-106.

7. Chiwocha SDS, Dixon KW, Flematti GR, Ghisalberti EL, Merritt DJ, et al. (2009) Karrikins: A new family of plant growth regulators in smoke. Plant Science 177: 252-256. 
Citation: Sarva SAK, Giri A (2014) Effect of Freshwater Crab Shell Fog as Organic Fertilizer to Increase Plants of Cucurbitaceae Growth Dramatically. Agrotechnol 4: 129. doi:10.4172/2168-9881.1000129

Page 4 of 4

8. Nalini S (2004) Vishvavallabha (Dear to the World. The Science of Plant Life). Agri-History Bulletin 5: 134

9. Kulkarni MG, Light ME, Staden JV (2011) Plant-derived smoke: Old technology with possibilities for economic applications in agriculture and horticulture. South African Journal of Botany 77: 972-979.
10. Balasubramanian AV, Devi TDN, Merlin M (2010) Report of the Literature Survey of Ayurvedic use of animal products in traditional agriculture, Franco Centre. 